\title{
Political Correctness: the Twofold Protection of Liberalism
}

\author{
Sandra Dzenis ${ }^{1}$ (D) - Filipe Nobre Faria ${ }^{2}$ \\ Received: 26 February 2019 / Accepted: 21 May 2019 / \\ Published online: 17 June 2019 \\ (C) Springer Nature B.V. 2019
}

\begin{abstract}
As understood today, political correctness aims at preventing social discrimination by curtailing offensive speech and behaviour towards underprivileged groups of individuals. The core proponents of political correctness often draw on post-modernism and critical theory and are notorious for their scepticism about objective truth and scientific rationality. Conversely, the critics of post-modern political correctness uphold Enlightenment liberal principles of scientific reasoning, rational truth-seeking and open discourse against claims of relativism and oppression. Yet, both the post-modern proponents and their Enlightenment liberal critics make up two sides of the same phenomenon of political correctness. Both sides intend to protect a liberal value system from illiberal truth-claims, which is the function of politically correct regulation. While post-modern advocates attempt to promote liberating tolerance, Enlightenment liberals place liberal values above the open-ended search for truth. Despite appearances to the contrary, this socio-academic debate is not about two sides favouring and opposing political correctness. In fact, it is a debate about the type of politically correct regulation that can better guard liberal values.
\end{abstract}

Keywords Political correctness $\cdot$ Liberal science $\cdot$ Liberating tolerance $\cdot$ Enlightenment . Post-modernism $\cdot$ Politics of speech

\section{Introduction}

As a term, political correctness (PC) is regularly present in the political lexicon of the contemporary West. The term now refers to a concrete social phenomenon with broad

Sandra Dzenis

Sandra.Dzenis@kcl.ac.uk

1 Department of Political Economy, King's College London, London, UK

2 Nova Institute of Philosophy, Nova University of Lisbon, Lisbon, Portugal 
recognition. Although defining PC can be contentious, according to the Oxford Dictionary of New Words, PC is 'conformity to a body of liberal or radical opinion on social matters, characterised by the advocacy of approved views and the rejection of language and behaviour considered discriminatory or offensive' (Knowles and Elliott 1997). As we understand it, this definition adequately describes the nature of the phenomenon; hence, it is the reference throughout the article.

Even though it is possible to trace back the term's origin to historical forces such as Marxism and Maoism (D'Souza 1991; Hildebrandt 2005), many critics of the term understand its modern meaning as an invention of the political Right to marginalise the Left's efforts to reach a more egalitarian society (Feldstein 1997; Sparrow 2002; Wilson 1995). These critics think the political Right invented the concept of PC to strengthen the right to dominate women and minorities, including racial minorities and homosexuals. Whatever its origins, the term is more popular among detractors of the content of PC. Accusing someone of PC 'has become a sarcastic jibe used by those, conservatives and classical liberals alike, to describe what they see as a growing intolerance' that shuts down debate with accusations of 'sexism, racism and homophobia' (R. Bernstein 1990).

While some political egalitarians defend certain aspects of PC (Fish 1994), others accept parts of the conservative critique (Gitlin 1995; Lea 2009). Some others, like Richard Rorty (1998, pp. 81-82), regard PC as a product of civilization that reflects 'a basic desire to tolerate, not persecute, those who have different faiths, beliefs, or skin colour' (Roxburgh 2002, p. 302). Although perhaps few people would claim to be believers in PC as a label, the term widely represents the advocacy of censorship that aims at protecting vulnerable groups. In social discourse, the term identifies a practice with ideological advocates regardless of whether they identify with the PC label. In this sense, the social impact of the term justifies the choice of PC over less impactful terms such as self-censorship (Cook and Heilmann 2012) or conformity (Williams 2016).

Debates about PC have focused on the consequences PC brings to academic freedom and political discourse (Bloom 1987; Cole 2006; Kimball 1990; Lukianoff and Haidt 2015; Moller 2016; Williams 2016). Within this overarching socio-academic debate, we detected a general argumentative trend that divides claims in favour and against PC into two epistemic and normative camps characterised as follows:

(1) the post-modern-like advocates of PC who favour regulating speech and behaviour to achieve social justice (Fish 1994; Lawrence 1990; Matsuda 1993) and

(2) the Enlightenment liberals who oppose PC by upholding truth-seeking open discourse and scientific rationality (Chait 2015; Furedi 2016; Pinker 2017; Pinker 2018; Rauch 2013).

This dichotomy arose when the second camp denounced the first one and adopted a comprehensive anti-PC stance. ${ }^{1}$ The aim of this paper is to show that this dichotomy does not hold up under scrutiny. We argue that

\footnotetext{
${ }^{1}$ The two camps battle over epistemological differences. If there is no substantive truth - as in post-modernist discourse -, potential claims for tolerance of offensive viewpoints in the name of truth and open discourse may lose their value. In this sense, the normative clash between the two camps involves asserting the epistemic status of scientific truth. Not everyone must identify with one of the two camps. Some may, for instance, support certain levels of PC while upholding scientific realism. Yet, supporting PC within science requires science-based supporters of PC to justify why truth is less relevant than restricting viewpoints for moral reasons, which again brings the epistemic dimension to the fore. Epistemology is key in the current PC debate.
} 
(1) no visible camp is in fact defending an open-ended scientific discourse, that

(2) $\mathrm{PC}$ is a protection mechanism of liberal values and that

(3) both sides represent PC.

The current debate is in reality about how to protect liberal values.

The structure of the argument is the following. First, the paper traces back the ideological roots of PC to core liberal values and goes on exploring how PC's function is to protect and further liberalism. Then, it claims the post-modern abandonment of enlightened truth-seeking is a particular form of PC, which attempts to protect liberalism from illiberal forces. Afterwards, the paper argues that although Enlightenment liberals claim to oppose PC, they still impose it by only engaging with truth-claims within the liberal framework. At the close, we show that science does not commit itself to liberalism.

\section{$2 \mathrm{PC}$ as a Mechanism to Protect Liberty and Equality}

PC emphasises a strong inclusive position, according to which individuals require moral equality in all aspects of life regardless of their religion, race, age, ethnicity, sex or gender. To enforce this attitude, PC advocates may use affirmative action or restrict free speech with speech codes and anti-discrimination laws (D. E. Bernstein 2003, pp. 1-4). However, Glenn Loury suggests that PC also implies conformity to a desired opinion on socio-political matters, which proliferates via social pressure:

(...) the more subtle threat is the voluntary limitation of speech that a climate of social conformity encourages. It is not the iron fist of repression, but the velvet glove of seduction that is the real problem. Accordingly, (...) the PC phenomenon [can be treated] as an implicit social convention of restraint on public expression, operating within a given community. (...) Members whose beliefs are sound but who nevertheless differ from some aspect of communal wisdom are compelled by a fear of ostracism to avoid the candid expression of their opinions (Loury 1994, p. 430).

Given the existing social pressure for conformity of beliefs, a scrutiny of the ideological or moral underpinnings of PC is of importance to understand its ontological constitution. In particular, there is a strong connection between politically correct (pc) attitudes and specific liberal values, such as individual freedom and equality, to an extent that it is possible to understand PC as being underpinned by liberalism.

As Michael Freeden points out, although the fluidity of liberalism may force us to acknowledge its existence in the plural, 'liberalism is a particular configuration of political concepts that has a loose but identifiable morphology' (Freeden 2008, p. 12), of which liberty and equality are identifiable central values common to all liberal versions. This specific liberal morphology makes it possible to address liberalism in the singular, thus distinguishing it from other value systems. Still, PC seems to fit better with a vertical conception of liberalism - also understood as welfare or social liberalism -, which promotes upward social movement and relies on positive conceptions of freedom. Positive freedom emphasises the need to remove the inhibitions of any social structure that prevent 
individuals from exercising their free will, inhibitions such as economic hardship, classism or racism. Such a conception of liberalism understands that unhindered self-realisation is illusory and therefore achieving real freedom and equality requires communal and state assistance. The pc approach also relies upon the idea that individuals of marginalised groups require assistance from community and state when struggling against offensive attitudes. Censoring offensive speech and attitudes that hinder the freedom of these individuals can be a way to free them from oppressive social structures.

A horizontal conception of liberalism - also regarded as constitutional or classical liberalism - seems to be less amenable to PC. This conception of liberalism emphasises free choice, dispersed knowledge and constitutional protection of negative liberties. Negative liberty is freedom from external restraints on the actions of individuals, something associated with minimal state representations. According to these representations, authority focuses on protecting direct harm and not on removing structural obstacles to achievement. The communal and state actions that would legitimise PC under a vertical/social conception of liberalism sit uneasily upon the horizontal/classical conception. The reason being that the latter conception relies on negative freedom. Thus, the laissez-faire attitude coming from a negative conception of freedom is more amicable to uncensored speech. Yet, as we will show later in the article, even a more horizontal/classical liberal position can use PC to defend liberalism. It can do so by endorsing a culture of voluntary ostracism towards illiberal viewpoints.

Subject to the condition that - overall - legal equality is in place in liberal democracies, pc attitudes focus mostly on substantive or enabling equality, an equality that aims at levelling departure points and enabling achievements. A pc position also emphasises the freedom of the individual, meaning every individual should be free from constraint to pursue one's own notion of a 'good life' (Rawls 1993, p. 19). This ethical pluralism entails that different notions of the good life are of equal value as long as these notions respect basic universal freedoms. And it ties to liberal pluralism in the sense that free individuals should be eligible to follow their own perception of the ethical life.

In consequence, a pc attitude manifests itself by assuming that the desired freedom for individuals in society is attainable by implementing not only formal but enabling equality (e.g. affirmative action, women's quota, etc.). In addition, pc positions inhibit the accentuation of certain individual and group differences to prevent unequal treatment. For instance, it is pc to deny or at least downplay innate human differences because these differences may explain inequalities of outcome (e.g. the gender pay gap). Pc thought seems to rely on the assumption that the way to achieve the most significant goal of individual freedom is through (a certain type) of equality.

Scholarly literature suggests that liberal thought has its foundation in the legacy of the Enlightenment (Brink 2000; Byrne 1997; Waldron 1993; Zafirovski 2011). As noted by Bert van der Brink (2000, p. 13), the idea of equality rests upon the liberal notion that all human beings hold the fundamental right to respect due to their status as reasonable and free individuals. The belief that the individual mind can gain genuine knowledge and grasp the fundamental principles of the world led to the conclusion that we should treat all reasonable beings as equals. As John Locke argued, nobody should ever be 'subjected to the Political Power of another without his own Consent' (Locke 1988, II, sec. 95) given men's moral sameness in nature.

Likewise, the Enlightenment gave birth to human rights to protect the autonomy and equal liberties of individuals. Perhaps the practical implementation of some human 
rights requires a certain level of PC. How, for instance, can one expect ethnic minorities/LGBT members/disabled people to take part in the cultural and political life of the community ("UDHR," 2010, art. 27(1)) if they feel marginalised by some members of society? Thus, PC advocates campaign for speech codes and for conformity of thought towards minority groups in order for these groups to enjoy their complete human rights. Also, the right to education ("UDHR," 2010, art. 26(1)) may lead PC proponents to the conclusion that only with the help of affirmative action can certain minority groups enjoy their rights. Even trickier seems to be the right to liberty ("UDHR," 2010, art. 3). Some PC supporters claim unrestricted speech and discriminatory behaviour threatens the liberty (and therefore a major human right) of affected human beings (Delgado 1982; Matsuda 1989; Parekh 2017).

\section{PC as Liberating Tolerance}

The most common advocacy of PC comes from contemporary post-modernists and critical theorists (Fish 1994; Lawrence 1990; Matsuda 1993; Rorty 1998) who often advocate forms of post-modern liberalism (Dryzek 2000, p. 27). But what is the standard intellectual source of this advocacy within PC-focused scholarship? When starting his essay 'Imagined tyranny'? Political correctness reconsidered, sociologist Paul Hollander puts forward the concept of repressive tolerance - introduced by Herbert Marcuse (1965) -, which is of high influence for 'the most widespread form of institutionalized intolerance in American higher education' (Hollander 1994, p. 51). Also, in their work The shadow university: The betrayal of liberty on American campuses, Kors and Silverglate (1998) argue that Marcuse's philosophy is the intellectual progenitor of PC at university campuses: 'The contemporary movement that seeks to restrict liberty on campus arose specifically in the provocative work of the late Marxist political and social philosopher Herbert Marcuse', who challenged 'the essence and legitimacy of free speech' (Kors and Silverglate 1998, p. 68). It is thus significant to set out Marcuse's theory of repressive tolerance, which this scholarly literature shows to be the birth hour of PC.

In his essay on repressive tolerance, Marcuse tries to figure out if there are ethical limits to tolerance and what consequences come from this enquiry. According to Marcuse, universal tolerance is only real when serving the cause of liberation and proper tolerance cannot arise as long as the holders of power and the guardians of the status quo indoctrinate society to keep inequalities stable. He considers it unfair to let the powerful and the powerless play under the same rules, because the powerful would always win and, as a result, would impose a violent and repressive agenda on the powerless. Hence, he points out that movements from the Left must replace the political Right. This replacement aims at implementing the Left's 'liberating tolerance' (Marcuse 1965, p. 109), which censors oppressive speech while expelling the Right's repressive tolerance, namely the repression operating under the guise of free speech.

Marcuse asserts that liberating tolerance is the only way to exercise (civil) rights and liberties for the oppressed. Hence, it should 'be enforced by the students and teachers themselves, and thus be self-imposed', withdrawing any 'tolerance toward regressive and repressive opinions and movements' (Marcuse 1965, p. 101). As a result, Marcuse's liberating tolerance, under which real freedom could flourish, should thrive first on university campuses before the concept encroaches upon the greater society: 
"This re-education alone could create a "progressive" society, where true freedom and democracy would reign' (Kors and Silverglate 1998, p. 71). While people outside academia may know little about Marcuse's formula for a progressive society, his prescriptions represent the paradigm for speech restrictions in the contemporary academic world. The liberal dimension of Marcuse's rhetoric is not always straightforward, perhaps because of his Marxist background. Yet, his philosophy suggests that universal liberties can only flourish within society if pc measures minimise the power and influence of any repressive establishment. Today's advocates of repressive tolerance are more explicit regarding the liberal aims of PC (Kernohan 1998; Levin 2010).

Contemporary social scientists advocating PC, such as Charles R. Lawrence, Richard Delgado and Mari Matsuda, build their research on race and gender bias upon Marcuse's idea of repressive tolerance (Delgado 1982; Lawrence 1990; Matsuda 1993); that is, on the idea that pc speech restriction applied to dominant/privileged groups allows for all members of society to experience equal freedom. Lawrence, for instance, notes that because white supremacy is the underlying message of racist speech, nonwhites experience limited life opportunities: 'There can be no true free speech where there are still masters and slaves' (Lawrence 1990, p. 481). Matsuda adds that official tolerance of racist speech on campus is harmful since it attacks 'the goals of inclusion, education, development of knowledge, and ethics that universities exist and stand for' (Matsuda 1989, p. 2371). In addition, Matsuda argues that individuals do not depart from an equal point. As a result, evaluating hateful speech regarding race/ethnicity must take the targets of such speech into consideration. Delgado concludes that racial speech cannot be part of the marketplace of ideas because instead of informing or convincing the listener, racial speech merely inflicts harm. Hence, such speech prevents the speaker and the listener from having a meaningful discourse (Delgado 1982, p. 177). By denying unrestricted freedom of expression, Delgado desires effective freedom in order for 'all citizens to lead their lives free from attacks on their dignity and psychological integrity’ (Delgado 1982, p. 181).

The arguments against robust free speech put forward by Lawrence, Matsuda and Delgado echo Marcuse's concept of repressive tolerance. In relation to implementing 'repressive tolerance' on campuses, Kors and Silverglate (1998) argue that university speech codes reflect Marcuse's idea of freedom and tolerance. They claim these Marcusian values try to balance the right of free speech with the right of not being harassed, to balance negative freedom with positive freedom. In this sense, speech restrictions assure liberty for some by limiting it for others.

Philosophers Andrew Kernohan and Abigail Levin, for instance, worry about state neutrality, which in the PC debate means unrestricted freedom of expression and a handsoff approach regarding the cultural marketplace. They argue that contemporary liberalism has given too much emphasis on tolerance at the cost of equality. Hence, there is a need for an advocacy strategy toward cultural reform, a compromise between unrestricted freedom of expression and coercive censorship by the state (Kernohan 1998; Levin 2010). In the same wavelength, Kernohan suggests state-promoted social conformity (i.e. PC). He points out that tolerance is not something for the enemies of liberalism to enjoy:

Liberalism requires tolerance of all manner of views on how to lead a worthwhile life, but not of views that deny the fundamental assumption of moral equality. (...) Liberal tolerance comes to an end for views (that are) inconsistent with 
liberal principles, and [that] threaten significant harm to society as a whole. (...) Therefore the liberal state must take an active role in reforming culture and combatting the cultural oppression of groups (Kernohan 1998, pp. 4-25).

Overall, contemporary liberal academics, such as Lawrence, Delgado, Matsuda, Levin and Kernohan, support certain pc measures on behalf of the liberal state to counteract oppression and social inequalities. The specific claims of Kernohan and Levin suggest that PC operates as a mechanism to promote and defend liberalism.

Some may argue that because critical or post-modern PC defends rights on the basis of group identity, it deviates from liberalism's commitment to ontological individualism, therefore becoming illiberal. This claim grows stronger because some early proponents of PC, such as Marcuse, came from a Marxist-influenced intellectual sphere. Yet, PC is not an illiberal phenomenon by necessity. In fact, group identity is often a liberating argumentative tool that marginalised individuals use against any oppressive institution which discriminates against them because of their group identity. In this sense, in order for individuals of unprivileged groups to enjoy liberty and equality, they need to emphasise their identity as the reason for their lack of equal liberty. We are not dealing with a novel issue. Throughout history liberals have used collective-based and identity-based concepts, such as the people, to overthrow non-liberal and allegedly oppressive political regimes (Eddy 2017). Due to their flexibility, liberal values often accommodate their egalitarian critics. In the words of John Dryzek:

Liberalism is the most effective vacuum cleaner in the history of political thought, capable of sucking up all the doctrines that appear to challenge it, be they critical theory, environmentalism, feminism, or socialism (Dryzek 2000, p. 27).

In particular, because egalitarian doctrines are many times in line with the moral desirability of liberal values, these doctrines can flourish within the fluid realm of liberalism. As for PC, the current and most common justification for its legitimacy relies on liberal concepts. Namely, speech restrictions are legitimate because they increase the liberties of individuals in marginalised groups by enhancing positive freedom, while these liberties deteriorate through negative freedom and unfettered critical discourse.

Not all authors following Marcuse's repressive tolerance may identify as liberals. Some would balk at applying the term liberal to their lines of thought. But their claims relating to PC take place in a liberal academic context and most of these authors use liberal normative concepts when justifying the censorship of particular speeches and actions (Delgado 1982; Kernohan 1998; Lawrence 1990; Levin 2010; Matsuda 1993).

\section{Post-Modern Liberalism: Scientific Rationality as Political Incorrectness}

While post-modern liberalism upholds the Enlightenment related values of individual liberty and equality, another Enlightenment value - that of autonomy reached by reason and pursuit of knowledge - fell by the wayside. 
As Immanuel Kant admonished in his 1784 essay An Answer to the Question: What Is Enlightenment?: 'Sapere aude! Have the courage to use your own understanding! is thus the motto of enlightenment' (Schmidt 1996, p. 58). He called for the enlightened individual to 'dare to know', to use reason in order to disenthrall itself from immaturity. John Stuart Mill also asserted that the autonomous individual 'must use observation to see, reasoning and judgment to foresee, activity to gather materials for decision, discrimination to decide, and when he has decided, firmness and self-control to hold his deliberate decision' (Ten 2008, p. 47).

However, Western liberal societies that impose speech codes, prosecute microaggressions and ban speakers with controversial opinions from university campuses do not fit the picture of this described Enlightenment ideal of critical discourse. Hence, the question comes up, why did the Enlightenment values of reason and scientific rationality lose their importance in post-modern liberalism while other Enlightenment-related values, such as (individual) freedom and equality are still being held up? Joanna Williams offers a possible explanation when stating that, after the experience of the Holocaust during World War II, the Enlightenment promoted value of reason and its respective methods (rationality, the search for truth and empirical evidence) plunged into crisis: 'The Holocaust was considered by many to be a logical consequence of the endeavour to shape society through science and rationality' (Williams 2016, p. 63). Science as 'the emancipation of reason from emotions, of rationality from normative pressures, of effectiveness from ethics' (Bauman 1989, p. 108) came out of World War II as a failure and a succour of the Holocaust perpetrators. For those liberals disillusioned by scientific progress, post-modern liberalism became a viable option. Conversely, those others who saw war events as a product of irrationality can stand by enlightened liberalism.

A certain disappointment regarding the desirability of science had a particular consequence. Namely, truth-claims and the vision that a particular body of knowledge should assist us in moving closer to the truth became disreputable within parts of academia, especially in the radical humanities disciplines. As a result, some insights of critical post-modernism such as truth being relative and multiple replaced enlightened rationalism. Critical theory, developed by scholars from the Frankfurt School and later carried on by post-modernists like Michel Foucault, often questioned that to pursue knowledge and rationality would simply lead to truth-claims. Instead, they pointed to the seductive power of images and words, which these scholars perceive as having the potential to shape reality and to harm people (Williams 2016, p. 133). In this sense, truth-claims would rather implement and reinforce pre-existing power structures in society. According to Max Horkheimer and Theodor Adorno, 'technical rationality today is the rationality of domination. It is the compulsive character of a society alienated from itself" (Horkheimer and Adorno 2002, p. 95). A critical and scientific discourse based on empirical evidence is then a tool of a political and economic power elite to strengthen its own position. In the words of Foucault:

Truth is to be understood as a system of ordered procedures for the production, regulation, distribution, circulation and operation of statements. 'Truth' is linked in a circular relation with systems of power which produce and sustain it, and to effects of power which it induces and which extend it (Foucault 1980, p. 133). 
As a result, this vision of truth and science 'undermines the ability to generate criteria for making ethical and political judgments, thereby threatening to plunge critical theory into relativism' (Bronner 2011, p. 33).

To be sure, not all critical theorists embrace post-modernism's incredulity towards universal scientific truth. For instance, Jürgen Habermas is a notorious critic of postmodern theory (Aylesworth 2015).

Yet, since its inception, critical theory emphasised how scientific and technological advancements are an instrument of domination in social relations (Horkheimer and Adorno 2002). Recent post-modern critical theory took one more step in this domination-oriented reasoning by casting out non-contingent scientific truth altogether. By doing so, critical post-modernism curtails the legitimacy of any potential governmental control undertaken in the name of objective truth. It is thus important to understand how bringing up epistemic relativism impacts the debate on PC.

First, there is not a single truth: Universities teach and uphold competing hypotheses. Still, there seem to be reservations towards making assertions that claim to be better and truer than other competing contentions. For example, while some feminist scholars (Grosz 1994; MacKinnon 1989; Prokhovnik 1999) claim physical differences between men and women (i.e. sex) are not responsible for behavioural differences (i.e. gender), there is a consensus among biologists, physicians and evolutionary psychologists that gender is (also) determined by biology (Baron-Cohen et al. 2005; Buss 1995; Hines 1982). However, these two competing assertions are both acknowledged within academia and are being taught on campus and published in leading international journals. Competing hypotheses within academia are the standard, but accepting no common standard of evaluation is likely to lead to parallel worlds of knowledge. Such worlds cannot assess one another without potential accusations of illegitimate authoritarianism.

Second, truth depends on perspective. The notion that knowledge is subjective leads way to contemporary identity politics. If truth is a personal construct, a heterosexual person, for instance, perceives the world in an entirely different way than a homosexual person. As a result, there cannot be a critical discourse about the accuracy of these two perspectives. None of them is truer than the other but they offer rather a distinctive point of view. According to some (Sue 2010; Waldron 2012), words have the potential to damage individuals at the psychological level; so to spread knowledge that historically disadvantaged groups and minorities may perceive as offensive is an act of aggression to avoid. Thus, it is not pc to claim certain knowledge is more valuable than another or to disconnect truth-claims from identity.

On the whole, contemporary post-modern liberalism has shifted away from the Enlightenment ideals of reason and scientific rationality. We may infer from the liberal egalitarian motivations behind this shift that liberalism neglected the value of striving for truth through knowledge and logic to protect itself from destruction via illiberal forces. As Michael Freeden notes, 'liberalism adapts through internal changes in the prioritization of its core concepts' (Freeden 2008, p. 15). And it seems adaptation was in order. What if because of a rational and scientific discourse someone established that individual freedom and universal equality are deficient ideas to construct the social order and that hierarchy and authority are systems which lead populations to greater success and satisfaction? By discrediting (objective) knowledge and critical reasoning, it is possible to diminish the potential danger of rational discourse for liberal tenets. In this sense, post-modern liberalism (Rorty 1992) seems to work as a purification of Enlightenment- 
liberal ideals, as an already tested and thus more robust version, which upholds certain liberal values, such as individual freedom and equality and therefore has to sacrifice idiosyncratic Enlightenment values, such as rationality and objective knowledge.

\section{Liberal Science: A Veiled PC}

As a reaction against post-modern PC advocates, Enlightenment liberals arose as the main opposing force to PC within socio-academic discourse. Although appearing to be fighting PC, this intellectual force ends up enforcing another version of the same phenomenon. Namely, they uphold science, reason and critical discourse but make sure potential illiberal findings or claims remain irrelevant. Enlightenment liberals defend liberal science ${ }^{2}$ against PC because they believe identity-based thought control endangers liberalism. In particular, these writers claim PC is authoritarianism - especially speech restriction -, which endangers liberalism in its most dominant appearances: liberal democracy and liberal science (Chait 2015; Green 2006; Rauch 2013).

In his work Kindly inquisitors - The new attacks on free thought, Jonathan Rauch describes the liberal intellectual system (liberal science) as the only alternative to authoritarian orders (Rauch 2013, p. 28). Notably, Rauch shows two ways to rescue liberalism by reintroducing the Enlightenment ideal of reason and critical discourse.

First, Rauch asks for de-relativising knowledge. That is, to let liberal science decide about correct hypotheses (i.e. having knowledge) and incorrect claims (i.e. just having an opinion): 'Checking of each by each through public criticism is the only legitimate way to decide who is right' (Rauch 2013, p. 6). Hence, Rauch criticises the egalitarian attempt to relativise knowledge by respecting multiple truths and claims researchers should detect truth via critical discourse within liberal science.

Second, Rauch objurgates what he calls the humanitarian threat (Rauch 2013, p. 111) by asserting that the possibility of critical discourse is of higher importance to liberalism than the harm that offensive truth-claims can do to disadvantaged/minority groups. In order for liberal science to identify real knowledge, it cannot be 'nice (...). It does not give a damn about your feelings and happily tramples them in the name of finding truth' (Rauch 2013, p. 19).

Hence, for Rauch, liberal science is the best mechanism to protect a liberal society from authoritarian measures. If everybody enjoys free speech and can put out truthclaims, the diverse scientific community sorts out the facts and disregards the errors. In this way, it is possible to avoid authoritarian decision makers who determine what is right and what is wrong: 'In an imperfect world, the best insurance we have against truth's being politicized is to put no one in particular in charge of it' (Rauch 2013, p. 110). On the one hand, according to Rauch, liberal science respects freedom of speech and belief; on the other hand, liberal science does not accept the right of beliefs to become knowledge straight away. Everybody can make claims all the time, but in order for claims to achieve the status of knowledge, they have to pass the process of the

\footnotetext{
${ }^{2}$ Liberal science is a term developed by Jonathan Rauch (2013) that represents an Enlightenment liberal intellectual system of knowledge production. It works with the following rules: no argument is really over; anyone can take part in scientific discussions. This system of knowledge production relies on the primacy of evidence and open discourse. As a term, liberal science remains in use, often by those opposing PC (Bailey 2005; J. Haidt and Lukianoff 2017).
} 
'science game for checking' (Rauch 2013, p. 116). The idea here is to avoid empowering a political elite who then decides if something is knowledge or not. Instead, a competent but also diffuse scientific community (with no special interest in claiming power) controls the process of knowledge verification.

It is at least doubtful if liberals, such as Rauch, obey their strict rules of scientific discourse. Regarding potentially offensive truth-claims, Rauch (2013, p. 129) suggests ignoring offensive beliefs when they are uncontested or if liberal science already showed them to be wrong. In the same way as the post-modernists, liberal scientists may fear that through reason one may conclude that a liberal polity is undesirable. In fact, rational discussions within the scientific community often marginalise truth-claims whose implications question contemporary liberal morality. For instance, Duarte et al. show that liberals embed their values into investigation fields and methods. As a result, these liberals keep other researchers away from 'politically unpalatable research topics (...): areas such as race, gender, stereotyping, environmentalism, power, and inequality' (Duarte et al. 2015, pp. 1-2). So, the liberal scientific community is more likely to ignore or marginalise illiberal claims. Yet, to advocate free speech does not imply to refuse PC. Just because a scientist may enjoy free speech, it does not mean he can expect his controversial work to receive an objective and rational feedback within liberal science. Science is far from being self-correcting in matters of moral and political sensibility when there is an overarching moral consensus (Cofnas 2016), as it is the case with liberalism (D. B. Klein and Stern 2005). PC measures, such as pushing academics to liberal conformism, protect liberal hegemony.

First, Rauch illustrates the push for liberal conformism when stating that one should criticise or ignore hurtful opinions (Rauch 2013, p. 159). He is obviously supportive of neglecting controversial - assumable illiberal - truth-claims instead of engaging with difficult issues. This is a common position (Horgan 2013; S. Klein 2017; McWhorter 2017; Rose 2009). For instance, political theorist Steven Klein argues that we should allow individuals to present controversial (illiberal) truth-claims, but we should prevent them from entering the academic debate. As he puts it:

Today, we've conflated a right to speak with a right to be taken seriously and debated. But while the former is a right, the latter is a privilege, and one that should be reserved for ideas that do not fundamentally threaten the foundations of our free and democratic society (S. Klein 2017). ${ }^{72}$

Also, Steven Pinker, who notably criticises the damaging effects of PC on social and scientific discourse, opens specific exceptions for the 'benign taboos on racism, sexism and homophobia' (Pinker 2018, p. 219). He clarifies that we should be 'mindful of excessive taboos' because they can diminish the credibility of journalists and academics (Pinker and (Producer) 2018), yet he is not claiming we should be mindful of liberal - taboos per se. This overall ethical approach can be partly responsible for young scholars avoiding controversial areas of research as it contributes to a climate of liberal conformity among academics.

Second, Rauch's claim that we should not try 'to silence or punish' people who hold discriminatory opinions but instead try 'to correct them' (Rauch 2013, p. 181) implies that truth-claims with discriminatory content are (morally) wrong and therefore we must amend them. Likewise, Pinker argues that academic free speech is necessary 
because freedom of expression allows us to use rationality to put controversial facts in a liberal context, which helps to avoid illiberal dangerous conclusions (Pinker 2017). Apparently, thinkers like Pinker and Rauch are self-assured that reason will never give support to non-liberal forms of political organisation. By this means, they show that they do not understand science as a process with an open outcome but as a process whose duty is to protect liberalism. There is also another stated reason for why potentially offensive speech should be permissible: 'And what about the day when right-wingers get the upper hand? Will they be "fair"?' (Rauch 2013, p. 143). It exists a latent fear that the 'inquisition' (Rauch 2013, p. 27) put in place by egalitarians and humanitarians to defend their vision of freedom and equality leads to authoritarian structures which an up-coming inegalitarian regime may use. A central aim of liberal science is to prevent illiberal political power from arising.

Enlightenment liberals advocate free speech and support the de-relativisation of knowledge. However, if their critical discourse only engages with claims and theories that remain within the liberal framework, if they ignore or marginalise claims outside this framework, they endorse a different kind of PC. Specifically, a PC that does not act authoritarian by forbidding offensive expressions and filing anti-discrimination laws but a PC that rather pushes people to perform self-censored conformist behaviour in order not to get marginalised. Liberal science worries that an authoritarian and identitydriven PC, as carried out by egalitarians and humanitarians, harbours the danger of triggering an illiberal identitarian counter-movement. As social psychologist Jonathan Haidt explains it:

If you keep treating white men as an identity group, you keep saying that 'they are terrible; they are evil' - eventually they become just like another identity group and they vote[d] their racial interests, in a sense you might say. So identity politics on the Left eventually triggers identity politics on the Right (Jonathan Haidt 2016).

Likewise, in defence of liberal science and moral individualism, the prominent anti-PC activist and psychologist Jordan Peterson clarifies that both identity politics - from the Left and from the Right - are 'equally dangerous' (Luscombe 2018). Thus, the tactic of ignoring, marginalising and not offering critical engagement with system-challenging opinions relies on the central goal of preventing the rise of identitarian illiberalism (Pinker and (Producer) 2018, p. 143; Rauch 2013). This goal and result oriented science promoted by Enlightenment liberals does not seem to have much in common with Kant's 'dare to know' attitude towards science. Instead, it bears similarities to Karl Popper's (1945) advocacy of intolerance towards illiberal discourses as the best way to protect the open society.

All in all, it is possible to understand that both the post-modern advocates of PC and their Enlightenment liberal opponents make up two sides of the same coin. On the side of post-modern PC, traditional Enlightenment values of reason and rationality got partly ejected from contemporary liberalism, being replaced by relativism and perspectivism. On the side of the Enlightenment liberals, there seems to exist liberal truth-claims that they do not debate and take for granted; so they marginalise or ignore claims challenging these pre-assumed positions. In this context, Williams asserts that Enlightenment liberals often assume that: 
the truth of a particular issue is settled beyond question. The tendency to label critics, or skeptics, on issues as wide ranging as the Holocaust, climate change, patriarchy and rape culture, as 'deniers' suggests not a clash of opposing understandings but that the truth has already been determined and people who do not accept it are deluded. It suggests that any further discussion is not only futile but problematic as it detracts from dealing practically with the issues concerned (Williams 2016, p. 67).

Williams understands that 'both the rejection of truth and the notion that the truth is settled curtail academic debate by undermining the assumption that knowledge progresses through competing truth claims' (Williams 2016, p. 67).

\section{PC and the Disconnection between Liberalism and the Enlightenment}

The moral positions that sprung from Enlightenment thought are not uniform. Particularly at the moral or ideological level, we can speak of Enlightenments, plural. Yet, Enlightenment liberals conflate liberalism and the Enlightenment as if these two concepts were interchangeable. The two concepts represent in fact two different traditions. As the likes of Nietzsche (2009) and Tocqueville (1959) realise, liberalism's defence of liberty and equality in universalistic and individualistic terms derives from Christian monotheism. In contrast, the Enlightenment defence of reason and scientific rationality evolved from ancient Greek thought, which often operated in a (pagan) nonliberal moral framework. Both Aristotelian and Platonic streams of thought were deeply biopolitical and strongly concerned with controlling the quality of population, therefore deriving moral worth from a hierarchical biological status (Ojakangas 2016). In this sense, to uphold scientific rationality does not require liberalism.

Without doubt, Enlightenment thinkers were not all liberal. Most notably, Auguste Comte's rejection of Christian-liberal metaphysics (e.g. human rights) led him to advocate a new 'religion of humanity', where scientific experts of the industry would discover the most appropriate moral framework for society (Comte 1927). As John Gray points out, 'the link between the Enlightenment and liberal values (...) is actually rather tenuous. It is strongest in Enlightenment thinkers who were wedded to monotheism, such as Locke and indeed Kant' (Gray 2018). Those unwedded to monotheism oftentimes espouse non-liberal values informed by science (Ojakangas 2016).

The close relationship between the Enlightenment advocacy of science and illiberalism is now an influential idea in scholarly terms, especially among critical perspectives (Geuss 1998). In particular, Adorno and Horkheimer's The Dialectic of Enlightenment (2002) disseminated the tight link between science and illiberalism. In this book, the two authors focus on the social consequences of instrumental reason, which is the capacity to discover effective means to satisfy whatever ends an agent may have. In its most sophisticated form, instrumental reason aims at finding scientific truth while remaining morally agnostic. They think the findings of empirical science alone cannot validate Enlightenment liberal ideals. For them, if facts are the single source of knowledge, 'in the end the (liberal) ideals themselves come to look like myths or prejudices which ought to be discarded' (Geuss 1998), thus opening the way to an 
explicit dominance hierarchy. However, the scientific knowledge of the natural world may be capable of identifying objective values - a standard philosophical position within natural moral realism (Richards 2017). But whether or not science can identify true moral values, Adorno and Horkheimer understand that Enlightenment liberal values are not free from naturalist scrutiny.

To embrace scientific rationality altogether - by removing it from unnaturalistic metaphysics - should mean that one is open to revising moral values according to the progress of knowledge. By making a case against PC and in favour of critical discourse, Enlightenment liberals should be open to moral revision. After all, morality is a social phenomenon thoroughly studied by science (Ruse and Richards 2017). Still, they do not show the willingness to revise their values according to science and continue to understand liberalism as having priority over scientific reason. For instance, Pinker claims scientific reason justifies liberal cosmopolitanism and disproves the value of ingroup favouritism. He asserts that

reason goads us into realizing that there can be nothing uniquely deserving about ourselves or any of the groups to which we belong. We are forced into cosmopolitanism: accepting our citizenship in the world (Pinker 2018, p. 11).

Yet, numerous scientific theorists demonstrate the importance of in-group favouritism in the evolutionary system (Axelrod and Hammond 2006; Faria 2017; Hartshorn et al. 2013), making his normative claim far from scientifically informed. The assertion that science only validates liberal values is another form of PC, which delegitimises illiberal scientific claims within the academic sphere.

Perhaps all ideological positions defend a set of values that demarcate no-go areas of belief, and liberalism is no exception. But one should not confuse the defence of values with PC. If not, all defences of certain value preferences over others would make up PC. Instead, the pc phenomenon is about silencing modes of expression antagonistic to one's value systems. ${ }^{3}$ What Enlightenment liberals do is not only to defend liberal values through reasoned rhetoric. Contrary to their open discourse narrative, they have an active role in silencing dissident voices by dismissing or overlooking illiberal truthclaims. Although outright censorship is not part of liberal science, this worldview engages in subtle mechanisms that restrict undesired positions.

For instance, liberal science conflates (liberal) value and (scientific) fact. By theoretically promoting critical discourse and the quest for truth, Enlightenment liberals seem to believe that no truth can ever justify illiberal claims. They seem to think truth has already validated liberalism, therefore making it safe to ignore illiberal truth-claims, portraying these claims as the product of bad science (Barber 2013; Newby and Newby 1995). Pinker (2017) goes so far as saying that any empirical truth should appear in critical academic forums for academics to diffuse potential illiberal truth-claims. Likewise, self-described conservative author Andrew Sullivan claims dangerous findings on genetic group differences obliges us to

\footnotetext{
${ }^{3}$ Unlike other ideologies that do not sacralise free expression, liberalism has a special inner tension because freedom of expression is an important part of the traditional liberal ethos.
} 
establish a liberalism that is immune to such genetic revelations, that can strive for equality of opportunity, and can affirm the moral and civic equality of every human being on the planet (Sullivan 2018).

Enlightenment liberals set two levels of scientific truth-seeking, one open to most facts and another one closed to non-liberal moral claims deriving from threatening facts.

The scientific behavioural fields that study average genetic differences between social groups regarding race and sex provide several examples of how PC became a method to protect liberal values. For instance, Noam Chomsky notes that these studies are of 'no scientific interest and of no social significance, except to racists, sexists, and the like' (Chomsky 1988, p. 164). Distinguished psychologist Howard Gardner calls the researchers that find natural inequalities between groups 'bad guys' (Gardner 2009) and 'pseudo-scientists' (Gardner 2001, pp. 6-7). In turn, evolutionary philosopher Daniel Dennett reveals the classic strategy to protect liberal morality from dangerous findings that reveal natural inequalities between groups (e.g. IQ, personality traits):

if I encountered people conveying a message I thought was so dangerous that I could not risk giving it a fair hearing, I would be at least strongly tempted to misrepresent it, to caricature it for the public good. I'd want to make up some good epithets, such as genetic determinist or reductionist or Darwinian Fundamentalist, and then flail those straw men as hard as I could. As the saying goes, it's a dirty job, but somebody's got to do it (Dennett 2003, pp. 19-20).

Dennett seems to claim that these dangerous findings should remain outside of scientific discourse regardless of how good the evidence may be. Yet, he made no claims of legally forbidding research, which reminds us that PC, in the form of softcensorship, often operates without outright prohibition and instead manifests itself through social pressure towards conformity (Loury 1994, p. 430). On another occasion, Dennett (2006, p. 337) condemns lying about scientific facts when other political forces like Marxism do it, showing that the defence of liberalism justifies the means.

After surveying the scientific community's attitudes towards these 'dangerous' topics since the 1970s, Nathan Cofnas concludes that within the community there is a widespread acceptance of two central ideas:

(4) The prevailing morality requires that 'scientists should not conduct research that threatens to uncover facts that contradict these morally required beliefs' and

(5) the same morality 'requires people to hold certain beliefs regardless of the evidence’ (Cofnas 2016, p. 479).

Given these widespread beliefs, it is not surprising that Enlightenment liberals are merely engaged in another form of PC, which, although rejecting the post-modern disregard for the truth, equally disregards the importance of knowledge when it conflicts with liberal values.

Ultimately, both post-modern advocates of PC and Enlightenment liberals deliberately conflate fact and value. The former understand scientific knowledge not as truth but as a narrative of power, while the latter are interested in truth as long as it validates 
liberalism as objectively good. Remarkably, no side seems to believe in the strict separation of $i$ from ought, which is clear in the shared fear that the discovery of empirical facts can lead to illiberal normative claims. As philosopher Robert J. Richards showed in his defence of evolutionary ethics, the reason it is so complicated to separate is from ought is that moral justification

must ultimately lead to an appeal to the beliefs and practices of men, which of course is an empirical appeal. So moral principles ultimately can be justified only by facts (Richards 1986 , p. 286).

Because of this prevalent conflation of fact and value, the socio-academic debate about $\mathrm{PC}$ is actually a debate about how to better protect liberalism. Strikingly, there is a general absence of critiques of PC that are truly open-ended regarding (scientific) truth and its moral consequences, including those of a potentially illiberal nature. A possible explanation for this absence has two dimensions:

(6) the academic community is overwhelmingly liberal, leading to a general lack of moral diversity and to a weak pluralism (D. B. Klein and Stern 2005).

(7) PC itself, with its soft penalties at the social and professional levels, makes up a barrier against the existence of open-ended critiques of PC.

This leads us to a full circle where the debates about PC are themselves pc.

\section{Conclusion}

The socio-academic debate about PC presents a dichotomy between critical postmodern advocates of PC and those Enlightenment liberals who oppose PC. Yet, we showed that this dichotomy does not hold under scrutiny and that both sides are ultimately defenders of PC who merely use different pc strategies. In particular, Enlightenment liberals represent a concealed form of PC. Both sides are more interested in defending liberal values than in unfettered critical discourse. While postmodern advocates of PC straightforwardly dismiss objective truth, Enlightenment liberals uphold the existence and the desirability of truth. Yet, these science-based liberals are in fact protecting liberalism from an uncompromising open-ended quest for scientific truth.

As demonstrated, both sides use PC because PC works as a mechanism to protect and further liberal values. Its central aim is to prevent the rise of illiberal truth-claims. Hence, the socio-academic debate about PC is not a debate between two factions in favour and against PC, but a debate about how to better protect and further liberalism. It is a debate about the kind and degree of PC restrictions that can best defend liberalism from illiberal truth-claims and political stances. On one side, post-modern advocates wish to censor political incorrectness due to their understanding of some truth-claims as narratives of oppression. These advocates aim to suppress such narratives in the name of liberating tolerance. On the other side, Enlightenment liberals are more inclined to marginalise dangerous scientific research. Although falling short from banning dangerous speech, they reject the moral and scientific legitimacy of truth-claims that fall 
outside of the liberal paradigm. Enlightenment liberals often assert that certain (liberal) truth-claims are scientifically sound and beyond sensible debate.

Last, by noting that the Enlightenment differs from liberalism, we argued that Enlightenment principles of truth-seeking and critical discourse may also operate in non-liberal moral spheres or lead to them. Hence, to conflate liberalism and Enlightenment reveals not a commitment to open-ended scientific rationality but, above all, a commitment to liberalism and its (PC) safeguard. The debate on PC lacks a prominent anti-PC side arguing for an open-ended critical discourse at the scientific and moral levels, an absence likely caused by liberal hegemonic thought in academia and by PC itself. As a result, the PC debate represents a circular and closed dispute about how to uphold liberal values.

Acknowledgements We are grateful to Jonathan Anomaly and to three anonymous reviewers for their comments on earlier drafts. Their constructive criticisms strengthened this article.

Open Access This article is distributed under the terms of the Creative Commons Attribution 4.0 International License (http://creativecommons.org/licenses/by/4.0/), which permits unrestricted use, distribution, and reproduction in any medium, provided you give appropriate credit to the original author(s) and the source, provide a link to the Creative Commons license, and indicate if changes were made.

\section{References}

Axelrod, R., \& Hammond, R. A. (2006). The evolution of ethnocentrism. Journal of Conflict Resolution, 50(6), 926-936.

Aylesworth, G. (2015). Postmodernism. In E. N. Zalta (Ed.), The Stanford encyclopedia of philosophy.

Bailey, R. (2005). The triumph of liberal science. Reason. Retrieved from http://reason.com/archives/2005/12 /30/the-triumph-of-liberal-science

Barber, A. (2013). Science's immunity to moral refutation. Australasian Journal of Philosophy, 91(4), 633-653.

Baron-Cohen, S., Knickmeyer, R. C., \& Belmonte, M. K. (2005). Sex differences in the brain: Implications for Explaning autism. Science, 310(5749), 819-823.

Bauman, Z. (1989). Modernity and the holocaust. Cambridge: Polity Press.

Bernstein, R. (1990, 28 October). The rising hegemony of the politically correct. The New York Times.

Bernstein, D. E. (2003). You can't say that!: The growing threat to civil liberties from antidiscrimination laws. Washington, D.C.: Cato Institute.

Bloom, A. D. (1987). The closing of the American mind: How higher education has failed democracy and impoverished the souls of today's students. New York: Simon \& Schuster.

Brink, B. v. d. (2000). The tragedy of liberalism: An alternative defense of a political tradition. Albany: State University of New York Press.

Bronner, S. E. (2011). Critical theory: A very short introduction Retrieved from http://www. veryshortintroductions.com/view/10.1093/actrade/9780199730070.001.0001/actrade-9780199730070

Buss, D. M. (1995). Psychological sex differences: Origins through sexual selection. American Psychologist, 50(3), 164-168.

Byrne, J. M. (1997). Religion and the Enlightenment: From Descartes to Kant. Louisville: Westminster John Knox Press.

Chait, J. (2015, 26 January). Not a Very P.C. Thing to Say: How the language police are perverting liberalism. New York Magazine.

Chomsky, N. (1988). Language and problems of knowledge. The Managua lectures. Cambridge: MIT Press.

Cofnas, N. (2016). Science is not always self-correcting. Foundations of Science, 21(3), 477-492.

Cole, J. R. (2006). Academic freedom under fire. Daedalus, 134(2), 5-17.

Comte, A. (1927). Sociology and the new politics. American Journal of Sociology, 33(3), 371-381. 
Cook, P., \& Heilmann, C. (2012). Two types of self-censorship: Public and private. Political Studies, 61(1), 178-196.

Delgado, R. (1982). Words that wound: A tort action for racial insults, epithets, and name calling. Harvard Civil Rights-Civil Liberties Law Review, 17, 133.

Dennett, D. (2003). Freedom evolves. New York: Viking.

Dennett, D. (2006). Breaking the spell: Religion as a natural phenomenon. New York: Viking.

Dryzek, J. S. (2000). Deliberative democracy and beyond. Liberals, critics, contestations. Oxford: Oxford University Press.

D'Souza, D. (1991). Illiberal education: The politics of race and sex on campus. New York: Maxwell Macmillan International.

Duarte, J. L., Crawford, J. T., Stern, C., Haidt, J., Jussim, L., \& Tetlock, P. E. (2015). Political diversity will improve social psychological science. Behavioral and Brain Sciences, 38(130), 1-58.

Eddy, M. D. (2017). The politics of cognition: Liberalism and the evolutionary origins of victorian education. British Journal for the History of Science, 50, 677-699.

Faria, F. N. (2017). Is market liberalism adaptive? Rethinking F.a. Hayek on moral evolution. Journal of Bioeconomics, 19(3), 307-326.

Feldstein, R. (1997). Political correctness: A response from the cultural left. Minneapolis: University of Minnesota.

Fish, S. E. (1994). There's no such thing as free speech, and it's a good thing too. New York: Oxford University Press.

Foucault, M. (1980). Power/knowledge: Selected interviews and other writings, 1972-1977. New York: Vintage.

Freeden, M. (2008). European liberalism. An essay in comparative political thought. European Journal of Political Theory, 7(1), 9-30.

Furedi, F. (2016). What's happened to the University?: A sociological exploration of its infantilisation.

Gardner, H. (2001). The ethical responsibilities of professionals. In J. Solomon (Ed.), The good work project. Retrieved from http://thegoodproject.org/pdf/2-Ethical-Resp-of-Prof-7 98.pdf.

Gardner, H. (2009). Intelligence: It's not just IQ. The Rockefeller University: Parents \& Science. Retrieved from https://www.youtube.com/watch?v=ESGLRnitp4k

Geuss, R. (1998). Critical theory. Routledge Encyclopedia of Philosophy. Retrieved from https://www.rep. routledge.com/articles/thematic/critical-theory/v-1

Gitlin, T. (1995). The twilight of common dreams: Why America is wracked by culture wars (1st ed.). New York: Metropolitan Books.

Gray, J. (2018). Unenlightened thinking: Steven Pinker's embarrassing new book is a feeble sermon for rattled liberals. New Statesman. Retrieved from https://www.newstatesman.com/culture/books/2018/02 /unenlightened-thinking-steven-pinker-s-embarrassing-new-book-feeble-sermon

Green, D. G. (2006). We're (nearly) all victims now! How political correctness is undermining our liberal culture. London: Civitas.

Grosz, E. A. (1994). Volatile bodies: Toward a corporeal feminism. Bloomington: Indiana University Press.

Haidt, J. (2016) The psychology behind rising nationalism. BBC Newshour.

Haidt, J., \& Lukianoff, G. (2017). Why it's a bad idea to tell students words are violence. The Atlantic. Retrieved from https://www.theatlantic.com/education/archive/2017/07/why-its-a-bad-idea-to-tellstudents-words-are-violence/533970/

Hartshorn, M., Kaznatcheev, A., \& Shultz, T. (2013). The evolutionary dominance of ethnocentric cooperation. Journal of Artificial Societies and Social Simulation, 16(3), 7.

Hildebrandt, M. (2005). Multikulturalismus und Political Correctness in den USA (1. Aufl. ed.). Wiesbaden: VS Verl. für Sozialwiss.

Hines, M. (1982). Prenatal gonadal hormones and sex differences in human behavior. Psychological Bulletin, 92(1), 56-80.

Hollander, P. (1994). "Imagined tyranny"? Political correctness reconsidered. Academic Questions, 7(4), 51-73.

Horgan, J. (2013, 16 May). Should research on race and IQ be banned? Scientific American. Retrieved from https://blogs.scientificamerican.com/cross-check/should-research-on-race-and-iq-be-banned/

Horkheimer, M., \& Adorno, T. W. (2002). Dialectic of enlightenment: Philosophical fragments. Stanford: Stanford University Press.

Kernohan, A. W. (1998). Liberalism, equality, and cultural oppression. New York: Cambridge University Press.

Kimball, R. (1990). Tenured radicals: How politics has corrupted our higher education. London: Harper \& Row.

Klein, S. (2017, 6 November). Right-wing extremists have a right to speak, not a right to be listened to. The Washington Post. Retrieved from https://www.washingtonpost.com/news/posteverything/wp/2017/11/06 /right-wing-extremists-have-a-right-to-speak-not-a-right-to-be-listened-to/?utm_term=.792e263d2ade 
Klein, D. B., \& Stern, C. (2005). Professors and their politics: The policy views of social scientists. Critical Review, 17(3-4), 257-303.

Knowles, E., \& Elliott, J. (1997). The Oxford dictionary of new words (new ed.). Oxford: Oxford University Press.

Kors, A. C., \& Silverglate, H. A. (1998). The shadow university: The betrayal of liberty on America's campuses. New York: Free Press.

Lawrence, C. R. (1990). If he hollers let him go: Regulation racist speech on campus. Duke Law Journal, 1990, 431-437.

Lea, J. (2009). Political correctness and higher education: British and American perspectives. London: Routledge.

Levin, A. (2010). The cost of free speech: Pornography, hate speech and their challenge to liberalism. Basingstoke: Palgrave Macmillan.

Locke, J. (1988). Two treatises of government (student ed.). Cambridge Cambridgeshire. New York: Cambridge University Press.

Loury, G. C. (1994). Self-censorship in public discourse. A theory of 'political correctness' and related phenomena. Rationality and Society, 6(4), 428-461.

Lukianoff, G., \& Haidt, J. (2015, September). The coddling of the American mind. The Atlantic. Retrieved from https:/www.theatlantic.com/magazine/archive/2015/09/the-coddling-of-the-american-mind/399356/

Luscombe, B. (2018). Jordan Peterson talks gun control, angry men and why so few women lead companies. Time. Retrieved from http://time.com/5175974/jordan-peterson-12-rules-book-interview/

MacKinnon, C. A. (1989). Toward a feminist theory of the state. London: Harvard University Press.

Marcuse, H. (1965). Repressive tolerance. In R. P. Wolff \& B. Moore (Eds.), A critique of pure tolerance (pp. 81-117). Boston: Beacon Press.

Matsuda, M. (1989). Public response to racist speech: Considering the victim's story. Michigan Law Review, 87(8), 2320-2381.

Matsuda, M. (1993). Words that wound: Critical race theory, assaultive speech, and the first amendment. Boulder: Westview Press.

McWhorter, J. (2017). Stop obsessing over race and IQ. National Review. Retrieved from https://www. nationalreview.com/2017/07/race-iq-debate-serves-no-purpose/

Moller, D. (2016). Dilemmas of political correctness. Journal of Practical Ethics, 4(1), 1-22.

Newby, R. G., \& Newby, D. E. (1995). The bell curve: Another chapter in the continuing political economy of racism. American Behavioral Scientist, 39(1), 12-24.

Nietzsche, F. (2009). On the genealogy of morals. A polemical tract (I. Johnston, Trans.). Arlington, Virginia: Richer Resources Publications.

Ojakangas, M. (2016). On the greek origins of biopolitics: A reinterpretation of the history of biopower. Oxon: Routledge.

Parekh, B. (2017). Limits of free speech. Philosophia, 45(3), 931-935.

Pinker, S. (2018). Enlightenment now: A manifesto for science, reason, humanism, and progress. New York: Penguin.

Pinker, S. (Producer). (2018). Going rogue: Political correctness. World Economic Forum. Retrieved from https://www.youtube.com/watch?v=fFohRupaXzc

Pinker, S. (Writer) \& L. Liberty (Director). (2017). Is political correctness why trump won?, Spiked Magazine Panel.

Popper, K. R. (1945). The open society and its enemies. London: Routledge \& Kegan Paul.

Prokhovnik, R. (1999). Rational woman: A feminist critique of dichotomy. London: Routledge.

Rauch, J. (2013). Kindly inquisitors: The new attacks on free thought (expanded edition. ed.). Chicago: The University of Chicago Press.

Rawls, J. (1993). Political liberalism. New York: Columbia University Press.

Richards, R. J. (1986). A defense of evolutionary ethics. Biology and Philosophy, 1, 265-293.

Richards, R. J. (2017). Evolutionary ethics: A theory of moral realism. In R. J. Richards \& M. Ruse (Eds.), The Cambridge handbook of evolutionary ethics (pp. 143-157). Cambridge: Cambridge University Press.

Rorty, R. (1992). The priority of democracy to philosophy. In J. P. Reeder \& G. Outka (Eds.), The priority of democracy to philosophy (pp. 254-278). Princeton: Princeton University Press.

Rorty, R. (1998). Achieving our country: Leftist thought in twentieth-century America. Cambridge: Harvard University Press.

Rose, S. (2009). Should scientists study race and IQ? NO: Science and society do not benefit. Nature, 457, 786-788.

Roxburgh, A. (2002). Preachers of hate: The rise of the far far right. London: Gibson Square Books.

Ruse, M., \& Richards, R. J. (2017). The Cambridge handbook of evolutionary ethics. Cambridge: Cambridge University Press. 
Schmidt, J. (1996). What is enlightenment?: Eighteenth-century answers and twentieth-century questions. Berkeley: University of California Press.

Sparrow, R. (2002). Talking sense about political correctness. Journal of Australian Studies, 26(73), 119-131. Sue, D. W. (2010). Microaggressions in everyday life: Race, gender, and sexual orientation. Hoboken: Wiley. Sullivan, A. (2018). Denying genetics isn't shutting down racism, it's fueling it. New York magazine. Retrieved from http://nymag.com/intelligencer/2018/03/denying-genetics-isnt-shutting-down-racism-its-fueling-it.html

Ten, C. L. (2008). Mill's on liberty: A critical guide. Cambridge: Cambridge University Press.

Tocqueville, A. d. (1959). The european revolution and correspondence with Gobineau. New York: Doubleday. UDHR. (2010). The universal declaration of human rights, claiming human rights.

Waldron, J. (1993). Liberal rights: Collected papers, 1981-1991. Cambridge: Cambridge University Press.

Waldron, J. (2012, 20 March). The harm of hate speech. Free Speech Debate. Retrieved from http://freespeechdebate.com/discuss/the-harm-of-hate-speech/

Williams, J. (2016). Academic freedom in an age of conformity: Confronting the fear of knowledge. New York. Wilson, J. K. (1995). The myth of political correctness: The conservative attack on higher education. Durham: Duke University Press.

Zafirovski, M. (2011). The enlightenment and its effects on modern society. New York: Springer.

Publisher's Note Springer Nature remains neutral with regard to jurisdictional claims in published maps and institutional affiliations. 